\title{
Digital Native Librarians, Technology Skills, and Their Relationship with Technology
}

\section{Jenny Emanuel}

\section{INTRODUCTION}

A new generation of academic librarians, who are a part of the Millennial Generation born between 1982 and 2001, ${ }^{1}$ are now of the age to either be in graduate school or embarking on their careers. Often referred to as "digital natives" because their generation is believed to have always grown up online and with technology ubiquitous in their daily lives, ${ }^{2}$ many agree that this generation is poised to revolutionize library services with their technology skills. ${ }^{3}$

Younger academic librarians believe that their technology knowledge makes them more flexible and assertive in libraries compared to their older colleagues, and they have different ways of completing their work. They refuse to be stereotyped into the traditional "bookish" idea of librarianship and want to transform libraries into technology-enhanced spaces that meet the needs of students in the digital age, redefining librarianship. 4

This paper, as part of a larger study examining Millennial academic librarians, their career selection, their attitudes, and their technology skills, looks specifically at the technology skills and attitudes toward technology among a group of young librarians and library school students. The author initially wanted to learn if the increasingly high-tech nature of academic librarianship attracted Millennials to the career, but results showed that they had a much more complex relationship with technology than the author assumed.

\section{LITERATURE REVIEW}

The literature concerning the Millennial Generation focuses on their use of technology in their daily lives. Millennials are using technology to create new ways of doing things, such as creating a digital video for a term project, playing video games instead of traditional board games, and connecting with friends and extended family worldwide through email, instant messaging, and social networking. ${ }^{5}$ They use technology to create new social and familial networks with friends that are based on the music they listen to, the books they read, the pictures they take, and the products they consume. ${ }^{6}$ They believe that their relationship with technology will change the way society views and relates to technology. ${ }^{7}$ With technology at their fingertips on a nearly constant basis, Millennials have gained an expectation of instant gratification for all of their wants and needs. ${ }^{8}$

Jenny Emanuel (emanuelj@illinois.edu) is Digital Services \& Reference Librarian, University of Illinois, Urbana. 
Millennials believe that technology is not a passive experience, as it was for previous generations. ${ }^{9}$ To them, technology is active and an experience by which they live their lives. ${ }^{10}$ They have grown

up with reality television, which means anyone can have his or her fifteen minutes of fame. In turn, this means being heard, having their say, and becoming famous online are all natural experiences that can be shared by anyone. ${ }^{11}$ Because they can create their own customized media and make media consumption an interactive, as opposed to a passive and hierarchical, experience, they believe that everyone's opinion counts and deserves to be heard. ${ }^{12}$ Even though they believe they are the greatest generation and expert users of technology, others have a different view. For example, Bauerlein argues that they are not intellectually curious, are anti-library, and blindly accept technology at face value while not understanding the societal implications or context of technology. They also consume technology without understanding how it works. ${ }^{13}$

Within libraries, technology skills related to new librarians have been studied by Del Bosque and Lampert, who surveyed librarians from a variety of library settings with less than nine years experience working as professional librarians. The survey found the majority (55 percent) understood that technology played a large part of their library education, but a similar percent (57 percent) did not expect to work in a technical position upon graduation. Respondents also thought there was a disconnect between the technology skills taught in library school and what was needed on the job, with job responsibilities being much more technical than they expected. Thus, even though more experienced librarians expected recent graduates to fill highly technical roles, library school did not prepare them for these roles and students did not opt to go to library school to gain strong technology skills. Based on survey comments, the researchers noted two categories of new librarians: those who have a high level of technical experience, usually from a previous job in a technology related industry, and those who struggle with technology. For those who struggle with technology, technology was not the reason they decided to become librarians, and they wish their library school had more hands-on opportunities for technology instruction instead of teaching theoretical applications. ${ }^{14}$

\section{METHOD}

To understand, in part, the technology skills of Millennial academic librarians and their attitudes toward technology, the author developed a two-part research study including an online survey and individual interviews with Millennial librarians and library school students.

First, an exhaustive three-part survey was created covering multiple aspects of Millennial academic librarians, including demographics, career choice, specialization, generational attitudes, management, and technology skills. Although the survey focused on many areas of data collection, this paper focuses only on technology skills. The survey was disseminated in May 2012 to 50 American Library Association (ALA) accredited library schools in the United States as well as online outlets geared toward new librarians, including the New Members Round Table (NMRT) electronic discussion list, NextGen-l (Next Generation Librarians list), the ALA Emerging Leaders program alumni electronic discussion list, and the ALA Think Tank on Facebook. The survey was 
open for 10 days. The survey also asked participants if they would be willing to participate in a follow-up interview.

A total of 161 participants volunteered for a follow-up interview. Interviews began once the survey closed, and individuals were contacted via email to schedule an interview at their convenience. A total of 20 interviews were conducted in May and June 2012. The interviews were conducted using the audio-only function of Skype and were recorded using the MP3 Skype Recorder software. The author then transcribed all of the interviews and coded the transcripts.

The interview utilized open-ended questions to gather individual stories and offer support to the quantitative demographic and qualitative survey questions. ${ }^{15}$ The interview questions were semistructured and asked participants to explain in detail their path to becoming an academic librarian and their attitudes toward technology.

\section{RESULTS}

There were 315 valid survey responses. The birth years of participants ranged from 1982 to 1990 (see figure 1). The respondents were nearly evenly divided between library school students (45.5 percent) and individuals having already obtained a MLS degree (52.1 percent). Concerning the format of their library school program, 38.4 percent earned the degree at an institution entirely in person, 19.6 percent completed the degree entirely online, and 42.0 percent went to a program that was a mix of in person and online courses.

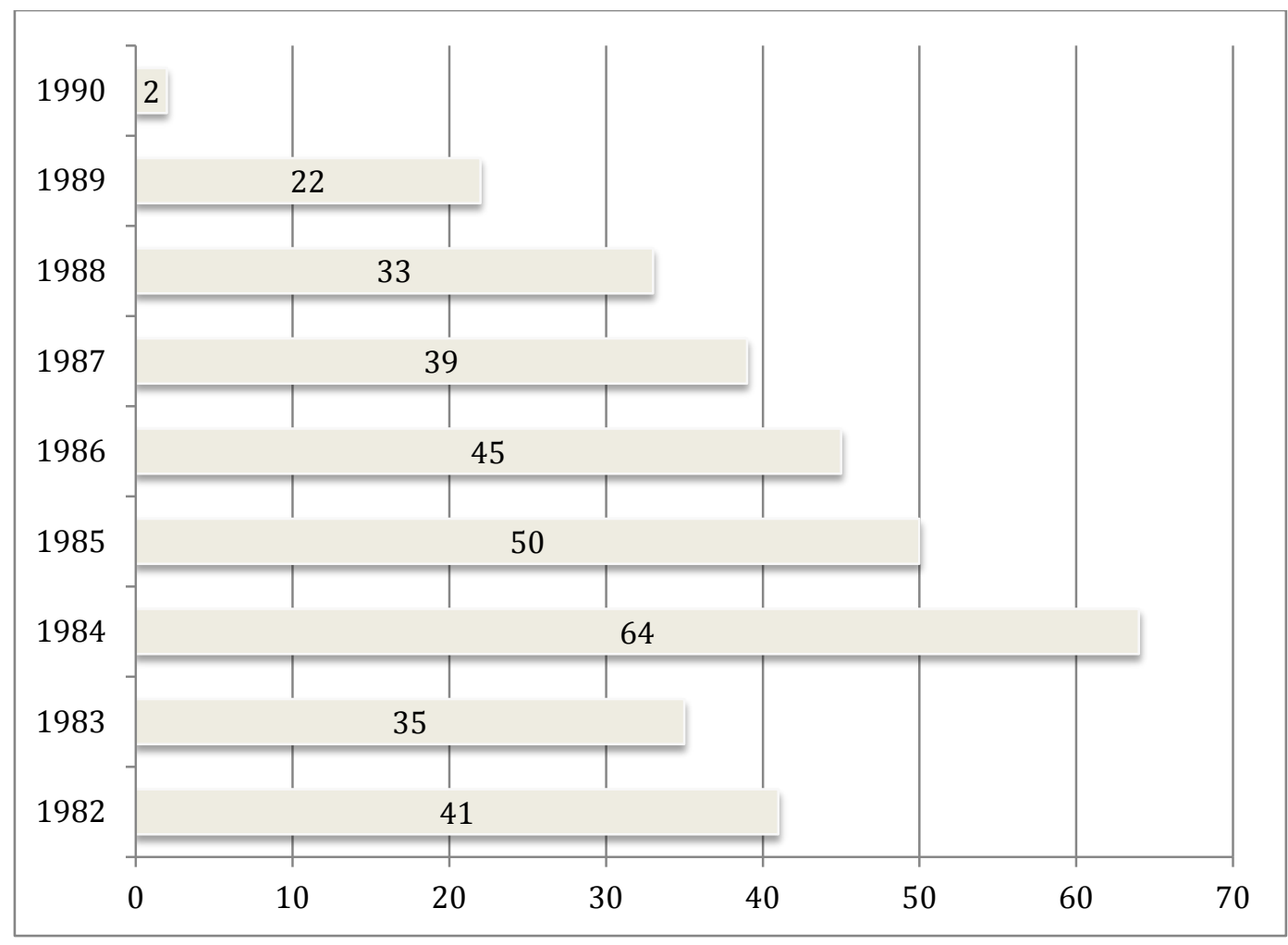

Figure 1. Birth-year distribution of survey participants. 


\section{QUANTITATIVE DATA}

Millennials believe it is very important for librarians to understand technology, with 99 percent reporting that it is important or very important. Data on skills related to technology were gathered through several questions, notably by using a list of technologies commonly used in academic libraries and asking respondents to rate their comfort level before starting library school, after library school, and at the present time. The results are illustrated in table 1.

\begin{tabular}{|l|c|c|c|}
\hline Technology & $\begin{array}{c}\text { Before } \\
\text { Library } \\
\text { School }\end{array}$ & $\begin{array}{c}\text { After } \\
\text { Library } \\
\text { School }\end{array}$ & $\begin{array}{c}\text { At the } \\
\text { Present } \\
\text { Time }\end{array}$ \\
\hline Adobe Dreamweaver & 1.93 & 2.5 & 2.46 \\
\hline Adobe Flash & 2.28 & 2.61 & 2.66 \\
\hline Adobe Photoshop & 2.66 & 3.15 & 3.22 \\
\hline Computer Hardware & 3.03 & 3.27 & 3.32 \\
\hline Computer Networking & 2.54 & 2.85 & 2.83 \\
\hline Computer Security & 2.56 & 2.96 & 2.91 \\
\hline Content Management Systems (CMS) & 2.34 & 3.32 & 3.29 \\
\hline Course Management Systems (Blackboard, Moodle, etc.) & 3.37 & 4.22 & 4.22 \\
\hline File Management Issues & 3.00 & 3.72 & 3.67 \\
\hline HTML & 2.56 & 3.56 & 3.48 \\
\hline Image Editing/Scanning & 3.47 & 3.87 & $\mathrm{~N} / \mathrm{A}$ \\
\hline Information Architecture & 1.86 & 2.67 & 2.58 \\
\hline Integrated Library Systems-Back End & $\mathrm{N} / \mathrm{A}$ & 3.05 & 2.93 \\
\hline Integrated Library Systems-Front End & $\mathrm{N} / \mathrm{A}$ & 3.53 & 3.39 \\
\hline Linux/Unix & 1.58 & 1.83 & 1.86 \\
\hline Mac OS X & 2.92 & 3.31 & 3.45 \\
\hline Microsoft Access & 2.55 & 3.19 & 3.26 \\
\hline Microsoft Excel & 3.94 & 4.37 & 4.40 \\
\hline Microsoft Windows & 4.57 & 4.67 & 4.71 \\
\hline Microsoft Word & 4.66 & 4.76 & 4.79 \\
\hline Mobile Devices & 4.27 & 4.51 & 4.60 \\
\hline PowerPoint & 4.43 & 4.62 & 4.65 \\
\hline Programming Languages (C++, .Net, etc.) & 1.53 & 1.94 & 1.84 \\
\hline Relational Databases & 1.87 & 2.66 & 2.66 \\
\hline Screen Capture Software (Camtasia, Captivate, etc.) & 2.10 & 3.26 & 3.32 \\
\hline Server Set Up/Maintenance & 1.56 & 1.85 & 1.84 \\
\hline Video Conferencing & 2.61 & 3.36 & 3.54 \\
\hline Video Editing & 2.28 & 2.90 & 2.94 \\
\hline Web 2.0 (RSS, Blogs, Social Networking, Wikis, etc.) & 3.79 & 4.54 & 4.49 \\
\hline Web Programming Languages & 1.55 & 1.99 & 1.92 \\
\hline XML & 1.60 & 2.40 & $\mathrm{~N} / \mathrm{A}$ \\
\hline & & & \\
\hline
\end{tabular}

Table 1. Average comfort level with technologies before and after library school and at the current time. Scale: 1 = very uncomfortable to 5 = very comfortable.

This list can be split into categories based on the level of technical skill required. Individuals were most comfortable with technologies that are used rather than technologies that enable people to create content, which generally require a higher level of skill. For example, people were comfortable with using content management systems (CMS) and software used to create 
webpages, such as Dreamweaver, but they were not comfortable with the information architecture skills, CSS, and HTML needed to create more complex websites. There was also a lack of understanding about relational databases, which serve as the back end of many online library resources that all librarians use to accomplish most reference work. Other deficiencies include Linux, an operating system commonly used to run servers, as well as server set up and administration, which run all web-based library resources and services. There is also a strong lack of computer programming understanding and skills, including $\mathrm{C}++$ and .Net, as well as web programming languages such as PHP, ASP, and Perl. However, when asked which technologies they would like to learn, respondents listed computer and web programming languages the most often, along with other high-level technology skills, including XML, database software and vocabularies, geographic information systems (GIS), Adobe Photoshop, and statistical software, such as SPSS.

Data from the technology questions also show that people are learning about technology in library school, but they are learning more about technology they already know how to use than technologies that are new to them. There are a couple of exceptions, including CMS, course management systems, HTML, and screen casting software, with which respondents grew notably more comfortable while in library school (see table 1). More than 84 percent of respondents were required to take a technology course in library school, and they generally believed library school prepared them well to deal with the technological side of librarianship, rating 3.23 on a 1-5 scale. However, respondents did note that most of their technology skill was self-taught (81.7 percent), with only 47.5 percent stating that coursework contributed to their skills.

An open-ended question asked what specific technology skills individuals wanted to learn. The results indicate that Millennial librarians desire to learn more of the higher-level technology skills, especially programming, which was indicated in 28 of the 97 responses. Other skills that were frequently noted include various elements of web programming, including scripting, XML, HTML, Photoshop, Microsoft Access, SPSS, and GIS. All of these skills either involve content creation (such as scripting, XML and HTML) or are complicated software that can require a great deal of training to master. See figure 2 for a tag cloud of technologies respondents want to learn.

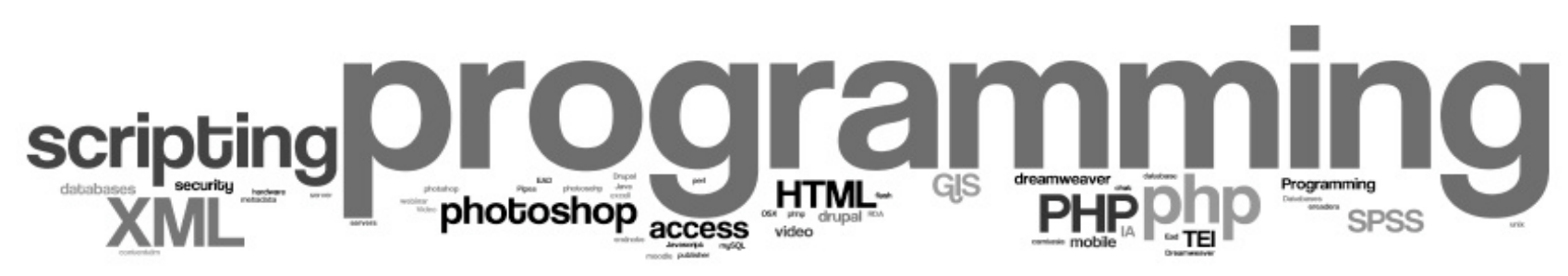

Figure 2. Coded tag cloud indicating responses to question, "Are there any other technologies you want to learn?" 
Clear trends emerged when Millennial librarians were asked about technologies that will be most important to libraries in five year. Mobile devices, including e-readers (such as the Amazon Kindle), apps, and tablet computers were the most common category of responses, followed by social media and social applications aimed at libraries. CMSs for managing website content was also very popular, and website design was also common. Advanced knowledge of database design, including relational database design, and the storage of library data frequently were mentioned, skills that were on a higher level than simply using databases to retrieve information online. Web 2.0 applications were also commonly mentioned, but it is unknown if these overlapped with social media. E-books, not unexpectedly, were very popular. The most popular technology individuals wanted to learn was programming, which came up 25 times, indicating there may be a gap in the technical skills that librarians have and the skills they need to have. See figure 3 for a visualization of coded responses.

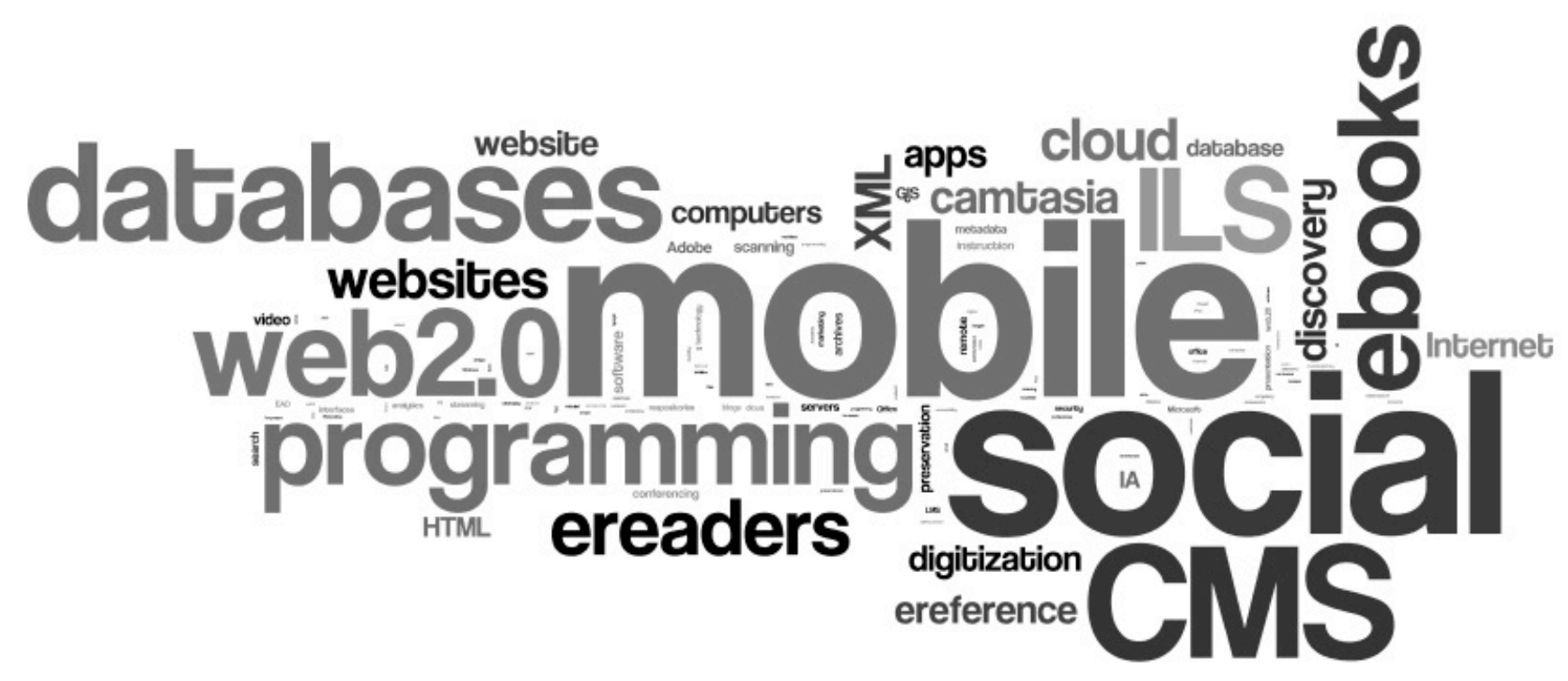

Figure 3. Coded responses to question, "What three technologies will be most important to libraries in five years?"

\section{QUALITATIVE DATA}

Interview participants exhibited a wide variety of diversity and roughly matched the demographics of survey participants. Demographic information for survey participants was gathered from their survey responses. Ten of the interviewees were born in 1984 or 1985 , with the remaining ten born during the remaining years between 1982 and 1989. Three participants were male, one did not indicate sex on the survey, and the remaining 16 participants were female. Fifteen identified their race as white, two African American, one Middle Eastern, one Hispanic, and one from multiple races. Interview participants were from 14 different states. All participants were given pseudonyms for purposes of data analysis. The interview transcripts were coded into 
broad categories, including attitudes about being digital natives, and technical skills relating to career choice.

\section{Digital Native}

Issues related to being digital natives came up often when Millennial librarians were asked to talk about their experiences using technology before they began library school, in library school, and on the job. However, not all considered themselves a digital native, very tech savvy, or able to pinpoint exactly what their tech skills are. Most, however, did believe that there were differences in technology use and attitudes between librarians who were younger versus older librarians.

\section{Childhood Technology}

Most remember when they first had a computer in their home as a child, so it was not a part of their lives from birth, but rather from a young age that most participants remember. Betty and Diana recall always having technology in their homes growing up because their parents worked in technology careers or had an interest in it as a hobby. As Diana stated, "Both [parents] worked in the IT field, so when I was really little, they spent an astronomical amount of money on a computer back in the mid to late 1980s, so I've always grown up with technology." Others remember first being exposed to computers in school, with Catharine saying, "I can remember being in elementary school and being on a computer and having specialized training. Not just in typing but they even pulled people out of class to learn how computers work." Heather vividly remembers her family getting their first computer: "We got one in my house when I was like in the sixth grade and that was a huge thing." Participants also remember having Internet access as a child. Betsy noted, "I had a Prodigy (online service) account when I was seven, when most people did not even know what the Internet was at that point." Gabby said, "I think they call people between 21 and 30 the 'in between', because they knew what it was like before technology, but they also know how to use technology ... because I remember before computers." Kelly talked extensively about how she grew up with technology:

I think we got our first computer when I was in the fifth grade. I definitely grew up with it. I used it in school. I remember what life was like before computers, though. I have that little bit of perspective there. But it was definitely part of my daily life. And in college I joined Facebook back when it was only for college students and now people cannot remember that now. But I used email, was one of the first users of Gmail. I got a little more into it in college.

Olivia also talked about her use of technology as a child:

We had a computer in my house. We were very fortunate because my dad was on top of that. So we had a computer since I was a little kid. So I would play around on that a lot, like AOL and Prodigy. I had the basic skills. And in high school we were taught basic word processing and Excel. So I've always been in front of a computer. 


\section{Concept of the Digital Native}

Most people believed they are digital natives because they have been working with technology for a long time, which sets them apart from older generations who they thought did not work extensively with technology until they were adults. Catharine stated, "I know it has been a part of my life forever so probably my age does have something to do with it." Catharine talked about the differences in technology skill between herself and her older colleagues, but added, "I don't feel there is an unwillingness for them to learn technology. I just don't think they had experiences at the time, where maybe we're just afforded more opportunities."

However, when pressed, not all considered themselves digital natives. Abby recalls a class discussion about the idea of digital natives and how younger people may not be as good with technology as they perceive. Because of this, she was hesitant to refer to herself as a digital native, even though growing up she believed technology was a part of her life. Others, such as Betsy, are reluctant to call themselves digital natives because they remember when their family first got a computer and it was not always in their household. There were also a couple of outliers who were reluctant to call themselves digital natives because they did not grow up with technology in the same ways as did many of their peers. Rachel grew up in a poorer home that always got technology second-hand, and she always thought they were behind others. Although her family first had an Apple Computer in the 1980s, she did not recall using it, and just thought of it as a sort of "new appliance" in her house. Her family did not emphasize technology use and saw it as something not worth investing in until they had to, which gave her a different perspective of using technology only as necessary and as “one of those things that sometimes I just don't want to deal with." Samantha grew up in a rural area that only had dial-up Internet, which embarrassed her and did not work as well as she thought it should, so she did not use it, leading to a belief that she did not grow up on the Internet in the same way as her peers. Because of this, she did not consider herself a digital native:

I'm still able to relate to those in a different generation who have no idea where to start [with technology], because I was at that state recently... I'm at the in-between stage, so I can handle both ends of the [technology use] spectrum. But yeah, I'm not a digital native.

\section{Technology Reaction}

Participants assumed that, because of their age, they were not as scared or intimidated by technology as they thought some of their colleagues were. Heather talked about how learning new things would initially make her nervous, but then would get excited about what the new program or application could do for herself or her work. Francis stated, "I'm not afraid of the technology." She also talked about the differences between herself and her older colleagues:

If you ask them something different or to learn something new, they will make it more complicated. I'm so used to exploring my options, I don't think about it. Those 20-30 years older than me are comfortable knowing what they know how to do but not necessarily exploring new ways of doing something that they already know how to do. They feel pretty comfortable and confident in their skills 
but aren't really looking to test the waters to see if there is a different way to do something.... I'm willing to try. I see a lot of people that are afraid they are going to break something and don't want to click on it. And I have the confidence that if I click on something, then I can pretty much undo whatever that does. So not necessarily skills, but a different mindset or something.

As Francis inferred above, younger librarians, because they have always used technology, believe they can quickly learn new technologies.

Quinn, a current student, also talked extensively about this:

I definitely think my age has a lot to do with how comfortable I am with it. Because there are various ages within [my library school] and I have definitely noticed that older people fear it a bit more. I guess I can attribute my age to being embedded in technology. Because I've always had it, well I haven't always had it, but I had it young enough to feel like it is a part of me, as opposed to new fangled and wasn't with it in the beginning... I'm not afraid of it, I'm not afraid to mess around with it and mess things up. Because you can always reboot or start over. I think that's the biggest thing, like I will work on something and mess around with it until I figure it out as opposed to someone who is older who wants to know something exactly the right way so they don't want to do anything bad to it.

Heather stated:

I think I'm a bit more open to new technologies than some of my older colleagues.... I have the feeling I know a little bit more... I'm not sure it is just because my comfort level was higher or maybe their experiences make them more cautious about new things, but I think the younger librarians are more quick to latch on to new things.

Other participants shared this same belief when talking about the difference in work styles and technology use among different ages in their workplace.

\section{Technology Skills}

The individual technology skills individuals described focus on the use of technology, not the creation of it. Francis described this:

I don't have any programming or coding [experience] or building physical computers or anything like that, but just general using a variety of devices like the iPad, iPhone, everything is all integrated. I like being able to use technology in my personal life.

No one responded that they knew how to program and work with servers, though Edward said he had "fiddled with Linux as a server" but did not spend a lot of time with it. Olivia and Quinn, however, did express interest in learning how to program, understand the back end, and create emerging technologies. Betty mentioned using SQL and XML in her workplace and aired her frustrations that people just expect to be able to use technology without learning how it actually works and what went into making that device or service. Several people mentioned working in web design, but only a couple people mentioned creating webpages with HTML and CSS, though several had experience using tools such as Dreamweaver or FrontPage. Ian mentioned that it was part of her public library job to assist patrons with using their personal devices, while others 
stated that when they have technology problems, they simply contact their IT departments. Many participants mentioned using social media and various Web 2.0 applications such as Facebook and Twitter, both personally and professionally.

When asked to compare their tech skills from before they became librarians to after, some described minor changes in skills, such as learning HTML, but others mostly indicated that library school helped them learn new applications, existing technologies, or new technology resources, most without going into detail. Quinn talked about her tech skills in relation to what she is learning in library school:

I think they [technology skills] are actually above average. I've taken a few of the courses that are offered in terms of tech, and they are totally below what I already know. But other classmates have thought it was really hard. But I've had prior knowledge of it.

Patricia stated she started using online tools more extensively after learning about them in library school. One talked extensively about using webinar software and LibGuides to deliver instruction online, while another stated library school inspired her to start a blog that she did not keep up, and another became an extensive Twitter user. Jan focused on digital librarianship while in library school because she saw it as the future of libraries. She thought that library school helped her do some "encoding on some projects and how to do webpages," but it barely touched on the skills needed to actually perform a job within digital librarianship. She would like to get more into the development side of library technology, but in her current job there is not the time or support to further advance those skills. A couple of participants talked about learning about usability and the evaluation of technologies.

A few interview participants mentioned the tech skills of people even younger than they are, or current college students they work with. Betty did not see younger coworkers understanding what is needed to develop or understand the back end of technology and believed younger workers do not use technology to communicate as effectively as they could. Edward, who works at a for-profit career college that has many poorer and nontraditional students, stated, it is "not just the 50 year olds, but the 18 year olds who don't know how to attach documents to an email." When pressed as to why she thinks young students struggle with basic technology tasks, he stated, "At times I think that has a lot more to do with their K-12 experience and if they had access to computers and stuff. I don't know. It just blows me away sometimes." Gabby, currently working in Appalachia, said, "Not everyone here has computer skills, not everyone has access to it at home or maybe can't make it to the library.... I think it is awesome to have those things at your fingertips, but not everyone does." On the other hand, Diana believed that she does not "have the same relationship with technology like I'm seeing some of the college students now where they are hooked in all the time and they are just going for it". She also said that she "wouldn't call myself a digital immigrant, but I'm very comfortable using technology but not to the extent I'm seeing many people I see now." 


\section{Tech Skills Related to Career Choice}

The researcher sought to determine the role of technology in determining the career choice of librarianship. Those interview participants who talked about using technology did not mention it as a reason they became a librarian. Survey responses indicated that opportunities to use technology were an important reason to become a librarian, but participants did not stress technology during the interviews. Participants were much more likely to specify their love of the academic atmosphere or their general interest in research first and then maybe think of technology as an afterthought. Gabby mentioned, after a long list of things that influenced her career choice, "and technology and stuff."

Only Taylor talked extensively about how technology influenced her choice. A current library school student, she wanted to go into archives and is really excited about how much information is being digitized and put online:

You know how everything on microfiche is now digital? Everything seems to be digitized as well, you know books and e-books and journals. Being able to take something and scan it and put it online for users to access. It is definitely an important thing. So yeah, that definitely influenced me on becoming a librarian.

Jan decided to specialize in digital librarianship while in library school because she saw it was the future of library work. Rachel, who has observed similar attitudes among her classmates, shared this thinking as well. However, Heather admitted she did not have a lot of technology experience before going to library school and did not believe that her master's program prepared her to go into the technology oriented digital librarianship.

Several participants talked about how their background using search engines such as Google and doing research online would make them better librarians, but none talked about these as factors related to choosing librarianship as a career. Abby talked about how she always uses Google to look things up, and that it is nice to have found a career that rewards such use. Diana discussed how she had always been good at finding information online since she was a child, which helped her narrow her career choice to academic librarianship, as she believed it was the best match for these skills.

Instead of talking about how technology influenced their career choice, participants were more likely to talk about the fact that technology did not influence them. Abby stated, "I don't think [technology influenced me] because I didn't really know that librarians needed a lot of technology skill." Edward stated he, "didn't do any technology in library school because I didn't want to go in that direction," reiterated this. Rachel, who strongly did not consider herself a digital native, stated she was drawn to librarianship, specifically access services, because she liked working with print books rather than using online resources to find information. She commented,

I really liked looking for books and I used the card catalog when I was a kid, but I can use a computer to help people find things, but it was like, I really just liked finding the books rather than electronic 
information. I guess I feel like it feels comfortable and safe, like books. And you can hold them and you can touch them. And sometimes I feel like they should always be a part of the library. I took a digital libraries course this past semester and I felt like I was the only one being like, "No, we still need physical books," so I was actually realizing how intimidated I am with technology. I'm totally willing to adapt, and I'm willing to work on these issues, but I do feel like I want the library to still be a place that has the traditional feel.

Samantha also did not feel like a digital native, as she grew up in a rural area that only had access to dial-up Internet. She went on to describe how she did not work with online tools until college and she was relieved when she did not have to use such tools during a year off between college and graduate school. Although she recognized technology use by librarians is helping libraries not becoming obsolete, she only learned what she needed to learn in order to complete library school, so it did not influence her career choice.

\section{IMPLICATIONS}

Millennials are very comfortable with technology, though there are limitations to their skills. For the most part, they have a lifetime attachment to technology, ${ }^{16}$ but they do remember a time without having a computer in their homes or when computers were something only used at school and for basic instruction. As interview participant Frances put it, "nothing like how students get to use them now." Millennial grew up with computers, but early on, they were not advanced enough to do the multimedia creation and application building that is done now, and they mostly use resources that were developed by others. However, Millennial librarians in this study do see the utility that computers have in everyday life, and by high school, many stated that computer use was required for them to go about their academic and personal lives, but they thought that technology in its current state with online research resources and social networking did not come about until they were in college. Additionally, most interview respondents said that library school helped acculturate them into using technology more frequently.

However, not everyone in the study grew up with a computer or Internet access in his or her home. Two interview respondents refused to call themselves digital natives. One said she grew up in an environment without much money, and the only technology her family had access to was often secondhand and several years behind. The other participant grew up in a rural area that did not have access to high-speed Internet, and as a result, she was rarely online until college. Both individuals believed that technology was definitely not a factor in them being drawn to librarianship, and they were more interested in the circulation and the print resources than in specializations that require a high level of technical knowledge. Other participants were quick to acknowledge that there are many members of their generation who, for one reason or another, do not have an interest in technology and may not have had the resources growing up to have incorporated it into their daily lives. Some participants noted there was some computer instruction starting in elementary school, but it was very basic computer literacy, and most of their technology learning occurred at home when there was the time to focus on tasks that were more complicated. 
Even though study participants remember a time without technology in their homes and they believe that technology did not mature to its current state until they were in college, they have used it for a much larger percentage of their lives than older generations. For that reason, they are quick to learn new technologies as they become available or are required based on professional needs. They also believe that because computers had matured alongside them, they are not afraid to break them. Interview participant Abby states, "I have a lot of faith in technology." Millennials believe that they can experiment with technology without fear that it will become inoperable or cause additional headaches in the future. They are also not wedded to particular technologies and do not get frustrated by current technologies and applications because they think something newer and better is always around the corner.

One disconnect in the technology skills of Millennials is that most of them are accustomed to using technology, not creating it or understanding the back end infrastructure. As one interview participant said, "they expect everything to be easy, but they don't understand what went into trying to make it easy." Although many librarians indicated they use tools such as Camtasia to create multimedia projects, many thought they had weak skills in this area and desired to learn more. They are also most likely to edit content on webpages using a CMS system such as Drupal or LibGuides instead of creating more elaborate websites utilizing information architecture principles or more complex web programming languages (such as PHP) or relational databases (such as MySQL). They rely on dedicated tech people to set these up and maintain the servers that house these services, but they desire to learn more about these technologies themselves. There is also a strong desire to learn more traditional computer programming languages such as $\mathrm{C}++, \mathrm{C \#}$, and Perl. Many participants thought library school only affected their technology skills marginally, and they desire to learn higher-order skills that can be applied to their job. Millennials are comfortable learning front-end technologies on their own, but they need help understanding the technology behind the tools they use in their daily lives.

\section{CONCLUSION}

This mixed-methods study examined many characteristics of Millennial librarians, and this article noted their technology skills and attitudes toward technology. The findings indicate that technology did not play a major role in their decision to become academic librarians. The data also reveal that, although Millennial librarians mostly grew up with technology and believe this sets their skills apart from older librarians, their skills are mostly in using technology tools and not in creating them. They also believe their status as digital native has allowed them to recognize that librarianship is changing as a career. However, Millennial librarians still respect their older colleagues and the skills associated with traditional librarianship and are firmly rooted in traditions. Millennial librarians just want to be able to shape the profession in their own way. 


\section{REFERENCES}

1. William Strauss and Neil Howe, Millennial and the Pop Culture: Strategies for a New Generation of Consumers in Music, Movies, and Video Games (Great Falls, VA: Life Course Associates, 2006).

2. Haidee E. Allerton, "Generation Why: They Promise to be the Biggest Influence since the Baby Boomers," Training and Development 55, no. 11 (2001): 56-60; Don Tapscott, Growing Up Digital: The Rise of the Net Generation (New York: McGraw-Hill, 2008).

3. Rachel Singer Gordon, The NextGen Librarian's Survival Guide (Medford, NJ: Information Today, 2006); Sophia Guevara, "Generation Y what can we do for You?" Information Outlook 11, no. 6 (2007): 81-82; Diane Zabel, "Trends in Reference and Public Services Librarianship and the Role of RUSA: Part Two," Reference \& User Services Quarterly 45, no. 2 (2005): 104-7.

4. Gordon, The NextGen Librarian's Survival Guide.

5. Gordon, The NextGen Librarian's Survival Guide; Lisa Johnson, Mind Your X's and Y's: Satisfying the 10 Cravings of a New Generation of Consumers (New York: Free Press, 2006); William Strauss \& Neil Howe, Millennial Rising: The Next Great Generation (New York: Vintage, 2000); Tapscott, Growing up Digital; Ron C. Zemke, Claire Raines, and Bob Filipczak, Generations at Work: Managing the Clash of Veterans, Boomers, Xers, and Nexters in Your Workplace (New York: Amacom, 2000).

6. Johnson, Mind your X's and Y's; Tapscott, Growing up Digital.

7. Strauss and Howe, Millennial and the Pop Culture.

8. Zemke, Raines, and Filipczak, Generations at Work.

9. Tapscott, Growing up Digital.

10. Strauss and Howe, Millennial and the Pop Culture; Tapscott, Growing up Digital.

11. L. P. Morton, "Targeting Generation Y," Public Relations Quarterly 47, no. (2002): 46-48; P. Paul, “Getting Inside Gen Y," American Demographics 23, no. 9 (2001): 42-49.

12. Paul, "Getting Inside Gen Y"; Tapscott, Growing up Digital.

13. Mark Bauerlein, The Dumbest Generation: How the Digital Age Stupefies Young Americans and Jeopardizes our Future (Or, Don't Trust Anyone under 30) (New York: Penguin, 2008).

14. Darcy Del Bosque and Cory Lampert, "A Chance of Storms: New Librarians Navigating Technology Tempests," Technical Services Quarterly 26, no. 4 (2009): 261-86.

15. Carol H. Weiss, Evaluation: Methods for Studying Programs and Policies (Upper Saddle River, NJ: Prentice Hall, 1998).

16. Allerton, "Generation Why "; Tapscott, Growing up Digital. 